\title{
Consumption of Traditional Leafy Vegetables (Amaranthus hybridus) and Risk of its Microbial Contamination in Daloa Town (Côte d'Ivoire)
}

\author{
Kouassi Kouassi Clément ${ }^{1,2^{*}}$, Attien Yao Paul ${ }^{1}$, Coulibaly Bakary ${ }^{1}$, \\ Diomandé Siriki $^{1}$, Benie Comoé Koffi Donatien ${ }^{3}$, Konate Ibrahim ${ }^{1}$ \\ and Koffi-Nevry Rose ${ }^{2}$ \\ ${ }^{1}$ Laboratory of Biochemistry and Microbiology (LBM), UFR Agroforestry, University of Jean Lorougnon \\ Guédé of Daloa, BP 150 Daloa, Côte d'lvoire. \\ ${ }^{2}$ Department of Food Science and Technology, Laboratory of Food Biotechnology and Microbiology, \\ University of Nangui Abrogoua, Abidjan, 02 BP 801 Abidjan 02, Côte d'Ivoire. \\ ${ }^{3}$ Laboratory of Biotechnology and Food (LBF), University of Félix Houphouët Boigny, 01 BP V4 \\ Abidjan 01, Côte d'Ivoire. \\ Authors' contributions \\ This work was carried out in collaboration among all authors. Author KKC designed the study, \\ performed the statistical analysis, wrote the protocol and wrote the first draft of the manuscript. \\ Authors AYP and CB managed the analyses of the study. Author DS managed the literature \\ searches. All authors read and approved the final manuscript. \\ Article Information \\ DOI: 10.9734/ARRB/2019/v33i330121 \\ Editor(s): \\ (1) Dr. Msafiri Yusuph Mkonda, Lecturer, Sokoine University of Agriculture, Tanzania. \\ Reviewers: \\ (1) Cristiane Ramos Vieira, University of Cuiabá, Cuiabá, Brazil. \\ (2) Saheed Olajide Oladeji, College of Science and Technology, Nigeria. \\ Complete Peer review History: https://sdiarticle4.com/review-history/51797
}

Original Research Article

Received 22 August 2019

Accepted 15 October 2019

Published 22 October 2019

\section{ABSTRACT}

Aim: It consisted to identify the different species of traditional leafy vegetables consumed, to follow the technical process of production and to specifically evaluate the risk of microbial contamination of Amaranth from urban production in Daloa.

Study Design: This study focuses on the consumption of traditional leafy vegetables.

Place and Duration of Study: University of Jean Lorougnon Guédé of Daloa, Côte d'Ivoire, Laboratory of Biochemistry and Microbiology, UFR Agroforestry, BP 150 Daloa, between November 2018 and April 2019. 
Methodology: On the study site, three planks of amaranth leave constituted a study block (sample). A total of 18 samples were analyzed. Then, mature Amaranth, ready for sale and then consumed, were subjected to microbiological characterization according to the standards.

Results: There are seven main species of leafy vegetables consumed by Daloa populations and Amaranth is one of the most widely consumed leaves. The monitoring of production of these vegetables revealed that many of the actors were adults ( $>30$ years old), dominated by the female gender $(63 \%)$ and illiterate $(70 \%)$. The inputs were poultry manure, a mixture of dung and beef purse. In addition, the technical production routes were empirical. Microbiological analyzes of Amaranth leaf from selected areas showed a high level of bacterial contamination. Including indicator of general pollution like mesophilic aerobic germs, yeasts and molds, enterobacteria and indicator of fecal origin were isolated. It has been noticed the presence of pathogenic species such as Staphylococcus aureus, Escherichia coli and Salmonella sp in all productions.

Conclusion: Amaranth leaves produced in this area aren't suitable for human consumption and could create some sanitary risk.

Keywords: Amaranthus; contamination; Daloa; traditional leafy vegetables.

\section{INTRODUCTION}

Urban agriculture has developed because of the growth of the urban population and the research of balanced diet. It is also created because of employment crisis and the impoverishment of the town's resident. This new food habits increases the number of market gardeners and multiplicate cultivated area in some big cities. In Côte d'Ivoire, urban and peri-urban agriculture is practiced most often on some inappropriate place in cities or around cities. Urban agriculture is growing quickly in large urban centers such as Abidjan, Yamoussoukro, Bouake and Daloa, where food needs are growing and diversified [1]. With rampant urbanization, the university town of Daloa is also confronted with profound changes in lifestyles, work activities, family and social relations, which crystallize the problem of food security. The direct benefit of this agriculture is the rapid supply of fresh produce from urban populations [1,2]. In addition, it produces economic and social functions for the city, through the direct and indirect jobs that it provides [3]. Several types of crops are made including the cultivation of leafy vegetables and especially traditional leafy vegetables. Traditional leafy vegetables, also known as leafy vegetables, refer to cultivated or wild plant species whose leaves are used in food $[4,5]$. The consumption of traditional leafy vegetables in general is highly recommended for protection against some diseases such as cancer, obesity, cardiovascular diseases and intestinal transit diseases [6]. They are important sources of nutrients (vitamins, protein, minerals, soluble fiber [7]. In Côte d'Ivoire, several traditional leafy vegetables have been reported: Corchorus (Corchorus olitorius); Amaranth (Amaranthus hybridus), Hen sorrel (Hibiscus sabdarifa), Black Nightshade (Solanum nigrum), Potato leaves (Ipomoea batatas), Celosia (Celosia argentea), Spinach (Spinach oleracea) and White caya (Cleome gynandra) [8]. Despite all the advantages of growing and eating traditional leafy vegetables, the health risks associated with the conditions of production are numerous. In Côte d'Ivoire, as in most developing countries, in difficult contexts marked notably by the lack of financial means for the supply of drinking water and synthetic fertilizers for soil fertilization, vegetable growers are motivate the using of wastewater for irrigation and animal manure as soil fertilizer $[1,9,10]$. In addition, rainwater runoff to these crops also carries other types of pathogenic microorganisms of fecal origin, largely from defecations of domestic or wild animals [11]. These practices could favor a high contamination of vegetables by microorganisms. Some of bacteria could be dangerous for the consumer. The author of the reference [10] said that the consumption of such vegetables could be a potential risk factor for infection with enteropathogenic bacteria such as Salmonella sp and Escherichia coli 0157. Cases of food poisoning linked to the ingestion of contaminated vegetables have been identified around the world [12]. Global annual estimates are in the order of tens of millions of cases of vegetable-transmitted diseases with often deaths and Africa remains proportionally the most affected [13]. It is therefore imperative and very important to minimize the risks of contamination of urban crops, particularly the traditional leafy vegetables. The context of this study was to help to show the risk and minimize the contamination of the traditional leafy vegetables. The objectives of this study were to identify the different species 
of leafy vegetables consumed by the populations, to follow the technical process of production and to specifically evaluate the risk of microbial contamination of Amaranth (Amaranthus hybridus) from urban production in Daloa. The data obtained can be used to sensitize producers to improve their process of growth and sanitary security of traditional leafy vegetables in Daloa.

\section{MATERIALS AND METHODS}

\subsection{Presentation of the Study Site}

The study area is Daloa town, located in the central west of Côte d'Ivoire between $6^{\circ} 3^{\prime}$ north latitude and $6^{\circ} 27^{\prime}$ west longitude. The site is a low-lying geographic coordinates $06^{\circ} 45^{\prime} 53.37^{\prime \prime}$ west longitude and $06^{\circ} 90^{\prime} 42.92^{\prime \prime}$ latitude north, located in the center of the city. Fig. 1 shows the geographical location of the study area.

\subsection{Surveys}

The biological material consists of Amaranth (Amaranthus hybridus). An investigation led to identification and the route of urban production of traditional leafy vegetables. The results of the survey are processed with statistical software SPSS 11.05. Recoding was done for data mining. The data is transmitted on Excel and MATLAB.

\subsection{Sampling and Methods}

On the study site, three planks of Amaranth leave constitute a study block. From each block, were selected three mature plants of Amaranth taken at random. A total of 18 samples for Amaranth were analyzed. These samples were packaged in a stomacher sachet and sent directly to the Microbiology Laboratory of the Jean Lorougnon Guédé University for analysis. An amount of $25 \mathrm{~g}$ of randomly selected sheet per sample is weighed aseptically around the flame on a scale (KERN) in paper-like and then spilled in a stomacher-type bag. A volume of 225 $\mathrm{mL}$ of sterile buffered peptone water (EPT) is added and closed. Everything was carefully mixed, taking care to soften the leaves with your fingers for two to three minutes. This suspension constitutes the stock solution. Microorganisms were revivified in $30 \mathrm{~min}$ or more before further handling.

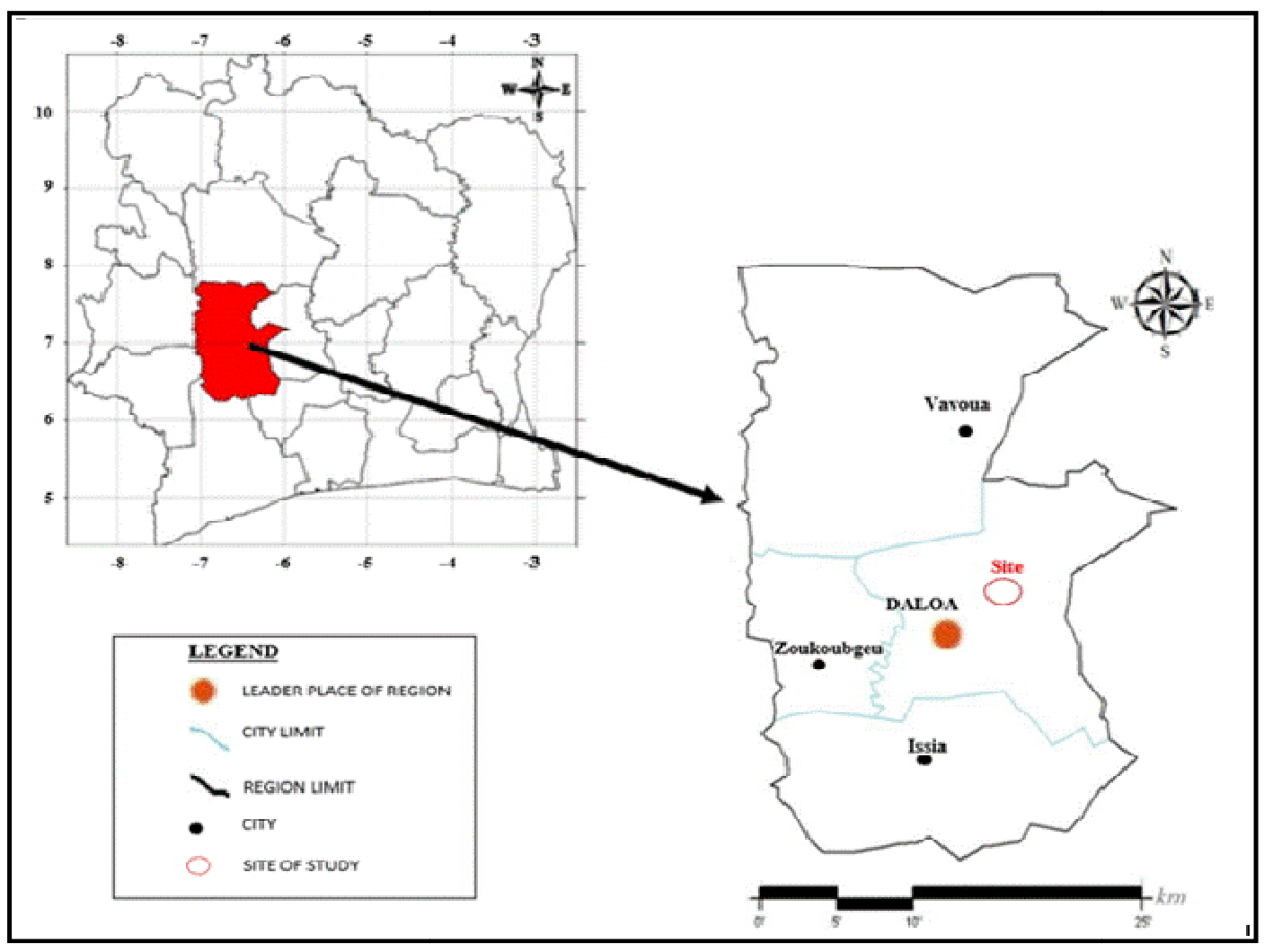

Fig. 1. Map of the city of Daloa presenting the study site 


\subsection{Decimal Dilutions}

They are obtained by mixing a determined volume of initial suspension with a 9 times equal volume of diluent. This operation was repeated on each dilution thus prepared, until a decimal dilution range appropriate for the inoculation of the culture media is obtained. Using a sterile pipette, $1 \mathrm{~mL}$ of the stock suspension is placed in a test tube containing $9 \mathrm{~mL}$ of sterile distilled water to obtain the $10^{-1}$ dilution. The mixture was made by means of a vortex-type stirrer during 5 to $10 \mathrm{~s}$. The operations were repeated on the $10^{-}$ 2 dilution and the following decimal dilutions, to obtain $10^{-6}$ dilutions. For inoculation of the culture media, dilutions $10^{-1}, 10^{-2}, 10^{-3}, 10^{-4}, 10^{-5}$ and $10^{-6}$ were used.

\subsubsection{Research and enumeration mesophilic total aerobic flora}

Using a sterile pipette, $1 \mathrm{~mL}$ of $10^{-3}, 10^{-4}, 10^{-5}$ and $10^{-6}$ dilution solution is removed and transferred to a sterile Petri dish (by dilution). This operation is repeated to obtain for each dilution two (2) Petri dishes. Then, about $20 \mathrm{~mL}$ of PCA Agar cooled to $50^{\circ} \mathrm{C}$ and were poured into each dish [14]. Homogenization was done by hand by slow and rotating movements. After solidification, the boxes were returned (lid to the shelf) and incubated in an oven at $30^{\circ} \mathrm{C}$ for $72 \mathrm{~h}$. Only whitish colonies were counted. The count was when the number of germs raised per box is between 30 and 300 colonies.

\subsubsection{Research and enumeration enterobacteriaceae}

Dilution tubes $10^{-1}, 10^{-2}, 10^{-3}$ and $10^{-4}$ were used and $1 \mathrm{~mL}$ of each dilution was removed and transferred to a sterile Petri dish (by dilution). This operation is repeated to obtain for each dilution two Petri dishes. In each dish, about 20 $\mathrm{mL}$ of VRBG Agar [15] cooled to $50^{\circ} \mathrm{C}$ in a water bath are cast. After homogenization (by a slow and circular movement) and the solidification of the medium, incubation of the dishes in an oven at $37^{\circ} \mathrm{C}$ in the inverted position for 24 hours. The colonies of red or pink color are typical of Enterobacteriaceae. The retained boxes contain between 15 and 150 colonies.

\subsubsection{Research and enumeration of yeasts and molds}

A volume of one milliliter of $10^{-2}, 10^{-3}, 10^{-4}$ and $10^{-5}$ dilutions of solution was collected using a sterile pipette and transferred to a sterile Petri dish (one for each box). This operation was repeated to obtain for each dilution two (2) Petri dishes, two tests. Then, about $20 \mathrm{~mL}$ of the medium Sabouraud Chloramphenicol cooled at $50^{\circ} \mathrm{C}$ in a water bath were cast in the same Petri dishes and the whole was homogenized by a slow and circular movement [16]. After drying, the dishes were inverted and incubated at $25^{\circ} \mathrm{C}$ for 5 days. Yeast colonies (white, creamy, transparent) and mold (downy, rough) were counted between 15 and 150 colonies characteristic after the incubation period.

\subsubsection{Research and enumeration of fecal coliforms}

Dilution tubes $10^{-1}, 10^{-2}, 10^{-3}$ and $10^{-4}$ were used. One $\mathrm{mL}$ of each dilution was removed and transferred to a sterile Petri dish (2 dishes per dilution). This operation was repeated to obtain for each dilution two Petri dishes. In each dish, about $20 \mathrm{~mL}$ of agar cooled to $50^{\circ} \mathrm{C}$ in a water bath are cast [17]. After homogenization (by a slow and circular movement) and the solidification of the medium, it follows the incubation of $44^{\circ} \mathrm{C}$ boxes for $24 \mathrm{~h}$. Characteristic colonies that were red are counted. The cotenants boxes considered for enumeration were those containing between 15 and 150 colonies.

\subsubsection{Research and enumeration of fecal streptococci}

One $\mathrm{mL}$ of the $10^{-2}, 10^{-3}$, and $10^{-4}$ dilutions was collected using a sterile pipette and transferred to a sterile Petri dish (one for each box). This operation was repeated to obtain for each dilution two (2) Petri dishes. Then about $20 \mathrm{~mL}$ of BEA agar medium was cooled to $50^{\circ} \mathrm{C}$ [18]. In a water bath, were cast in the same Petri dishes and the whole was homogenized by a slow circular movement. After the agar was set, the dishes were inverted and incubated at $37^{\circ} \mathrm{C}$ for 24 to $48 \mathrm{~h}$. Colonies characteristic of fecal streptococci appear black on BEA agar. Boxes containing 15 to 150 colonies were counted.

\subsubsection{Research and enumeration of Staphylococcus aureus}

The surface spreading method was used. Dilutions $10^{-1}, 10^{-2}$ and $10^{-3}$ were used. Seeding was carried out by spreading $0.1 \mathrm{~mL}$ of the solution on the sterile Petri dish already cast (containing medium Baird Parker base supplemented with egg yolk potassium tellurite + sulphamethazine $0.2 \%$ (antibiotic) [19]. After solidification of the boxes around the Bunsen burner, they are incubated in an oven at $37^{\circ} \mathrm{C}$ for 
48 hours. Black, shiny, convex colonies surrounded by a clear zone were enumerated. Only boxes containing between 15 and 150 were considered.

\subsubsection{Research and enumeration of Escherichia coli}

A volume of $0.1 \mathrm{~mL}$ of dilutions $10^{-1}, 10^{-2}$ and $10^{-3}$ was taken using a sterile pipette and then placed in a pre-cast sterile petri dish (Containing Rapid E. coli medium) [20]. This operation was repeated to obtain for each dilution two Petri dishes. After solidification around the Bunsen burner, the dishes were inverted and incubated at $44^{\circ} \mathrm{C}$ for 24 to 48 hours. After the incubation period bluish colonies between 15 and 150 characteristic colonies were counted.

\subsubsection{Salmonella search and enumeration}

It was done according to the following 3 steps, the pre-enrichment which was the incubation of the stock solution (EPT) at $37^{\circ} \mathrm{C}$ for $24 \mathrm{~h}$. The enrichment used the middle Rappaport Vassiliadis (RV). Volume of $0.1 \mathrm{~mL}$ of the preenriched stock solution was removed and transferred to a tube or $10 \mathrm{~mL}$ of $\mathrm{RV}$ was prepared beforehand and sterilized. After homogenization, the tube was incubated at $44{ }^{\circ} \mathrm{C}$ for 24 hours. The solute was derived from the incubated enrichment culture that was seeded on Hecktoen agar [21]. The boxes were incubated at $37^{\circ} \mathrm{C}$ for 24 or $48 \mathrm{~h}$. In this case, the absence of characteristic colonies was expected. The typical colonies observed were green or blue with a black center.

\subsection{Enumeration}

The calculation of the number of microorganisms per milliliter of sample (CFU/mL) from the number of colonies obtained in the Petri dishes chosen was carried out by the equation described by author of reference [22]. Standards for assessing microbiological quality and determining the origin of fecal contamination. The standards for assessing the microbiological quality of amaranth and potato leaf produced were taken from the Microbiological Criteria for Foodstuffs - Guidelines for Interpretation, 2015 of Luxembourg, supplemented by the normative reference of microbiological criteria of human foods (EC $n^{\circ}$ 2073/2005). The determination of the origin of fecal contamination was based on the criteria defined by authors of reference [22]. According to these authors, the contamination was of animal origin if the coliform fecal / fecal streptococci ratio indicates 0.7 and of human origin if this ratio was greater than 4.

\section{RESULTS AND DISCUSSION}

\subsection{Results}

\subsubsection{Survey results}

The survey conducted in the various markets of Daloa identified seven (7) species of traditional leafy vegetables consumed by Daloa populations: Ipomoea batatas, Corchorus olitorius, Amaranthus hybridus, Portulaca oleracea, Hibiscus sabdariffa, Solanum nigrum, Basela alba. Amaranthus (Amaranthus hybridus) is by far the most consumed of these traditional leaf species. The essential information of species was summarized in Table 1. The profile of the urban cabbage producers of the different sites investigated is summarized in Table 2. The profile of producers of traditional leafy vegetables has shown that market gardening is practiced mainly by women (63 \%) against only $37 \%$ for men. It is $90 \%$ dominated by adults aged 30 years and over; young people aged 18 to 30 represent only $10 \%$. Market gardeners are $72.72 \%$ illiterate. However, $21.21 \%$ and $6.06 \%$ of the producers claim to have attended school with a level of primary and secondary education respectively. As inputs, all these producers $(100 \%)$ use surface water to watering their crops. $55 \%$ of market gardeners use poultry manure and chemical fertilizer, $45 \%$ use chemical fertilizer, beef purse and poultry manure, beef purse and chemical fertilizer for fertilizing their boards. The technical itineraries to produce traditional leafy vegetables, particularly Amaranth, are summarized in Fig. 2. According to the survey, the quantities of fertilizers used were not measured.

\subsubsection{Microbiological characteristics of traditional leafy vegetables}

\subsubsection{Flores of contamination and floras of fecal contamination from Amaranthus hybridus}

The microbiological analysis conducted made it possible to assess the level of microbiological contamination of the two different traditional leafy vegetables. Amaranth produced was contaminated by different microbial flora: alteration microflora and some flora evoking deficit of good hygiene practices production. These are fungal flora (yeasts / molds), mesophilic aerobic germs and Enterobacteria. All 
samples from the study site were heavily contaminated by this different microflora. In addition, all feeds in CFU/g were all above the expected microbiological quality standards. The load in CFU/g for mesophilic aerobic germs ranged from $1.8 .10^{7}$ to $3.45 \times 10^{7} \mathrm{CFU} / \mathrm{g}$ whereas the standard only provides $10^{6} \mathrm{CFU} / \mathrm{g}$. For the fungal flora, the loads ranged from $10^{6}$ to $2.15 \times 10^{6} \mathrm{CFU} / \mathrm{g}$ while the standard predicts the value of $10^{4} \mathrm{CFU} / \mathrm{g}$. As for Enterobacteriaceae, the charges ranged between $1.27 .10^{6}$ and 2.4.10 ${ }^{6} \mathrm{CFU} / \mathrm{g}$ whereas the standard predicts a load of $10^{4} \mathrm{CFU} / \mathrm{g}$ (Fig. 3). All samples were heavily contaminated with fecal coliforms and fecal streptococci, and all loads exceeded the microbiological quality standards. The $\mathrm{CFU} / \mathrm{g}$ load for fecal coliforms ranged from $8.8 \times 10^{4}$ to $2.36 \times 10^{5} \mathrm{CFU} / \mathrm{g}$ Amaranth while the standard only provides $10^{2} \mathrm{CFU} / \mathrm{g}$. Fecal streptococci ranged from $1.23-10^{5}$ to $2.54 .10^{5} \mathrm{CFU} / \mathrm{g}$ Amaranth (Fig. 4). The CF / SF ratio is 0.99 . This result shows that the origin of fecal contamination of Amaranth is mixed predominantly animal (1> CF / SF> 0.7).

\subsubsection{Pathogenic flora of Amaranthus hybridus}

Amaranth samples analyzed were heavily contaminated with Escherichia coli, coagulasepositive Staphylococcus aureus and Salmonella $\mathrm{sp}$. It was noted both the presence of these three bacterial species in all samples with loads exceeding the prescribed standards. The load of Escherichia coli ranged from $7.10^{4}$ to $2.18 .10^{5}$ CFU/g whereas the standard only provides 10 to $10^{2} \mathrm{CFU} / \mathrm{g}$. That of $S$. aureus oscillated between $5.10^{4}$ and $1.09 .10^{5} \mathrm{CFU} / \mathrm{g}$ while the standard provides only $10^{2} \mathrm{UFC} / \mathrm{g}$ (Fig. 5). The Salmonella standard indicates 0 feed in $25 \mathrm{~g}$ of feed and therefore a complete absence, while all the samples analyzed had high Salmonella loads (Table 3).

Table 1. Main traditional leafy veggies consumed in Daloa and their characteristics

\begin{tabular}{|c|c|c|c|c|c|}
\hline $\begin{array}{l}\text { Vernacular } \\
\text { names }\end{array}$ & $\begin{array}{l}\text { Plants } \\
\text { species }\end{array}$ & Family & Taste & $\begin{array}{l}\text { Terapeutic } \\
\text { properties }\end{array}$ & $\begin{array}{l}\text { Fregency of } \\
\text { consomption }\end{array}$ \\
\hline Patate & $\begin{array}{l}\text { Ipomea } \\
\text { batatas }\end{array}$ & Convolvulaceae & Neutral & $\begin{array}{l}\text { Anemia, Hepatitis, } \\
\text { Diabetes, Toothache }\end{array}$ & ++++ \\
\hline kplala & $\begin{array}{l}\text { Corchorus } \\
\text { olitorius }\end{array}$ & Tilaceae & Neutral & Laxatives, Purgatives & ++++ \\
\hline Mamichou & $\begin{array}{l}\text { Amaranthus } \\
\text { hybridus }\end{array}$ & Amaranthaceae & Neutral & Anemia & ++ \\
\hline $\begin{array}{l}\text { Epinard } \\
\text { africain }\end{array}$ & $\begin{array}{l}\text { Portulaca } \\
\text { oleracea }\end{array}$ & Portulacaceae & Neutral & $\begin{array}{l}\text { Cardiovascular } \\
\text { disorders }\end{array}$ & +++ \\
\hline Dah & $\begin{array}{l}\text { Hibiscus } \\
\text { sabdariffa }\end{array}$ & Malvaceae & $\begin{array}{l}\text { Acid, } \\
\text { sour }\end{array}$ & Anemia & ++ \\
\hline Fassambrou & $\begin{array}{l}\text { Solanum } \\
\text { nigrum }\end{array}$ & Solanaceae & Bitter & Malaria, typhoid fever & ++ \\
\hline Epinard & Basela alba & Basellaceae & Neutral & Anemia & +++ \\
\hline
\end{tabular}

Table 2. Profile of urban producers and characteristics of traditional leafy veggies production

\begin{tabular}{llll}
\hline & & Frecency & Pourcentage \\
\hline Age (years) & {$[15-30[$ years } & 3 & 10 \\
& {$[30-60[$ years } & 22 & 73.33 \\
& $>60$ years & 5 & 16.66 \\
\hline Gender & Male & 11 & 37 \\
& Female & 19 & 63 \\
\hline Nationality & Ivorian & 18 & 60 \\
& Non Ivoirian & 12 & 40 \\
\hline Level of study & Iliterate & 21 & 70 \\
& Primary & 7 & 23.33 \\
& secondary & 2 & 6.66 \\
\hline Agricultural inputs & Surface water & 30 & 100 \\
& Poultry manure+ chemical fertilizers & 15 & 50 \\
& Poultry manure+ cow dung+ chemical & 15 & 50 \\
& fertilizers & & \\
\hline
\end{tabular}




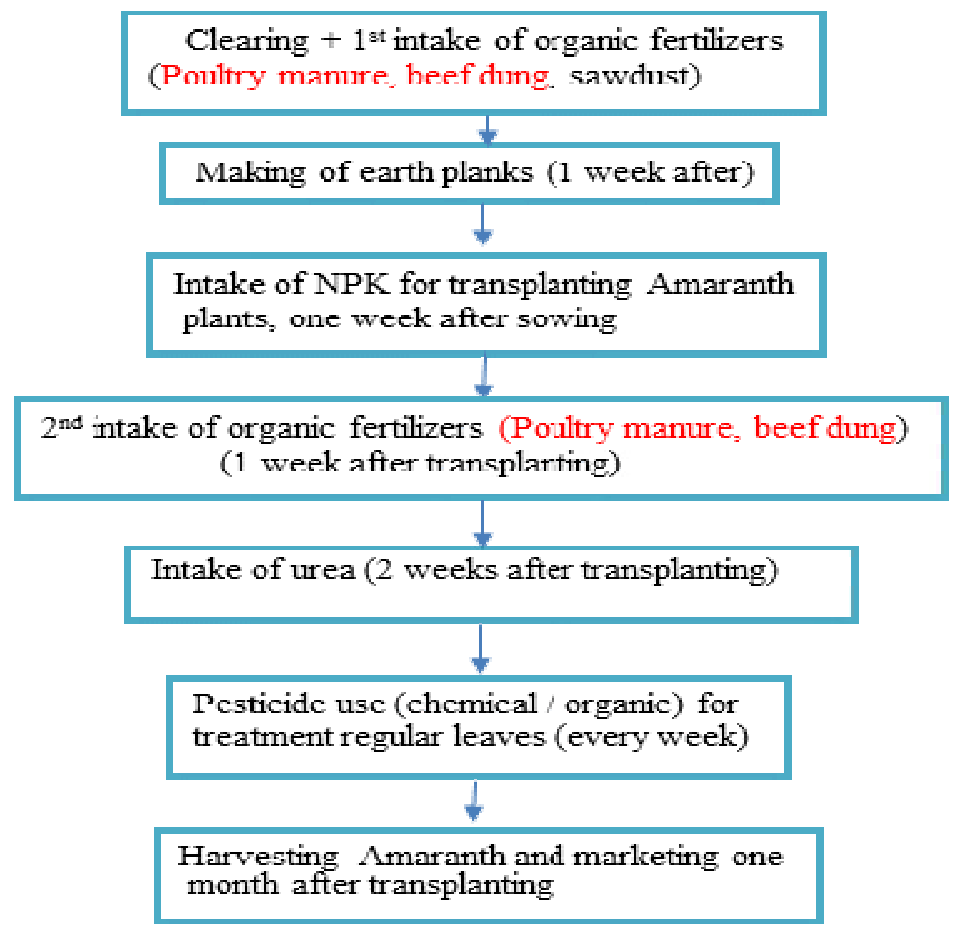

Fig. 2. Urban production process of amaranth (Amaranthus hybridus L.)

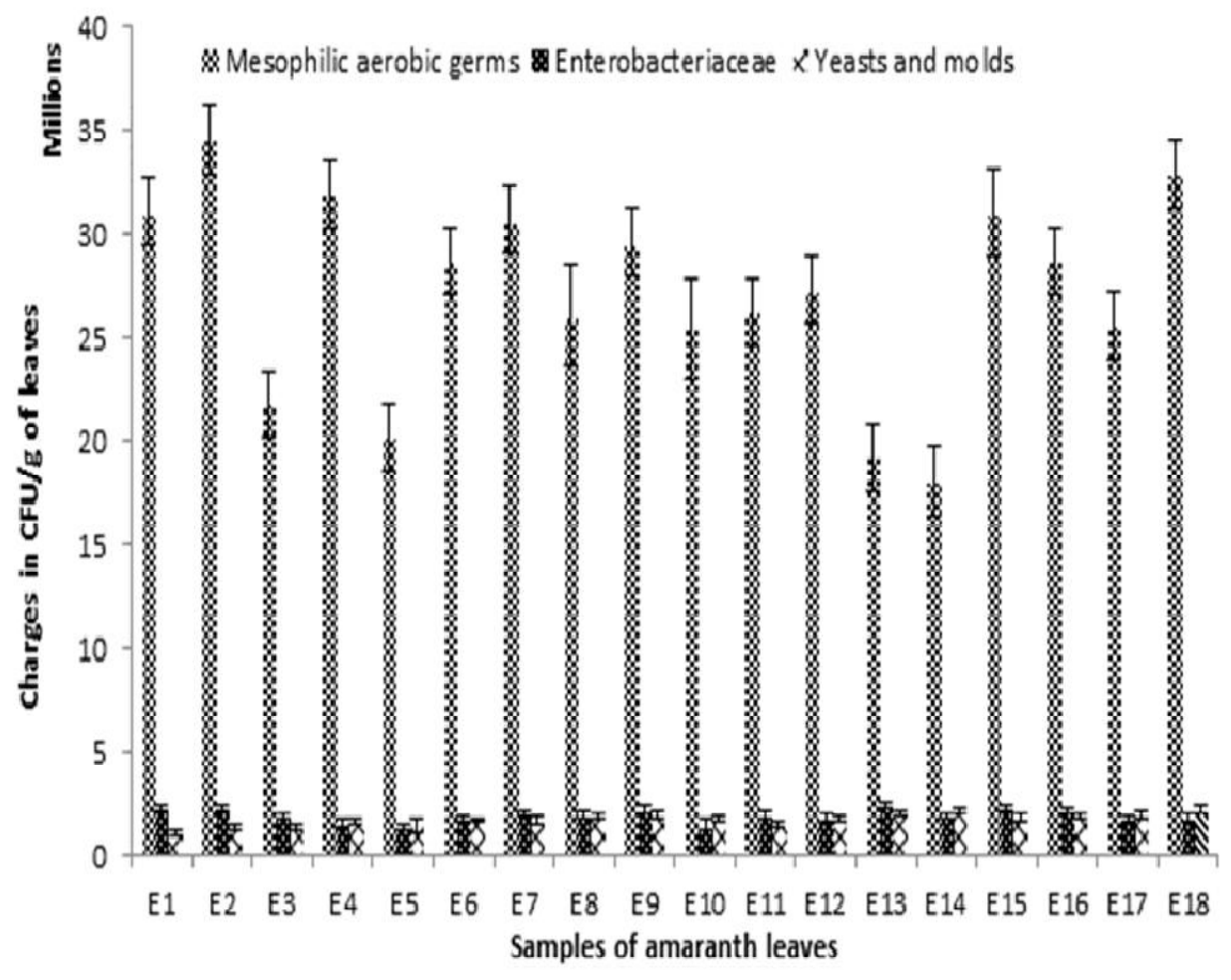

Fig. 3. Numbers in CFU/g of alteration microfloras in amaranth according to the samples 
Table 3. Presence of Salmonella in different amaranth samples

\begin{tabular}{lcccccccccccccccccc}
\hline \multicolumn{11}{c}{ Presence of Salmonella sp colonies } \\
\hline Sample of amaranth & $\mathrm{E}$ & $\mathrm{E}$ & $\mathrm{E}$ & $\mathrm{E}$ & $\mathrm{E}$ & $\mathrm{E}$ & $\mathrm{E}$ & $\mathrm{E}$ & $\mathrm{E}$ & $\mathrm{E}$ & $\mathrm{E}$ & $\mathrm{E}$ & $\mathrm{E}$ & $\mathrm{E}$ & $\mathrm{E}$ & $\mathrm{E}$ & $\mathrm{E}$ & $\mathrm{E}$ \\
leaves & 1 & 2 & 3 & 4 & 5 & 6 & 7 & 8 & 9 & 10 & 11 & 12 & 13 & 14 & 15 & 16 & 17 & 18 \\
\hline & +++ & +++ & ++ & +++ & + & ++ & ++ & + & ++ & + & +++ & ++ & ++ & +++ & + & ++ & ++ & + \\
\hline
\end{tabular}

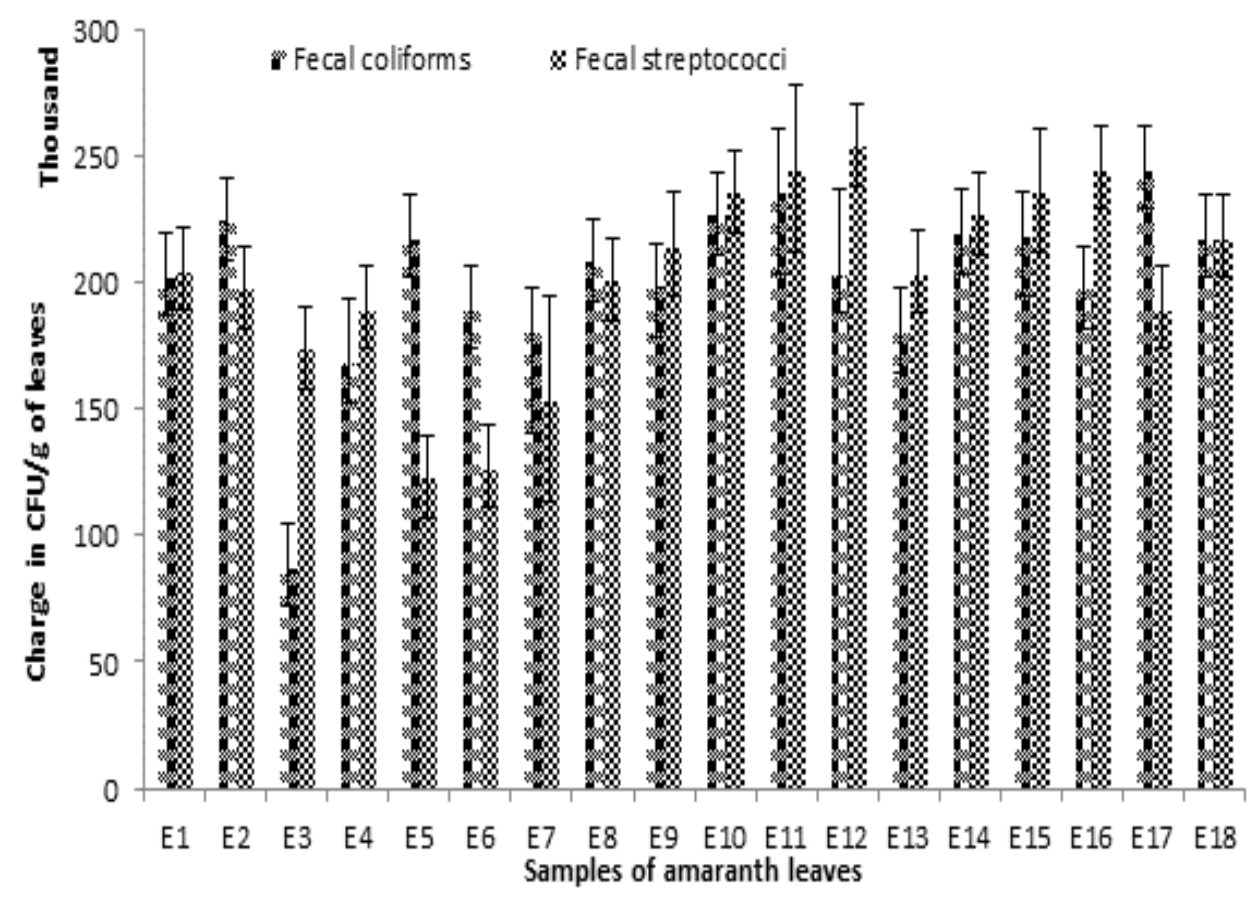

Fig. 4. Numbers in CFU/g of bacterial flora of fecal contamination in amaranth according to the samples

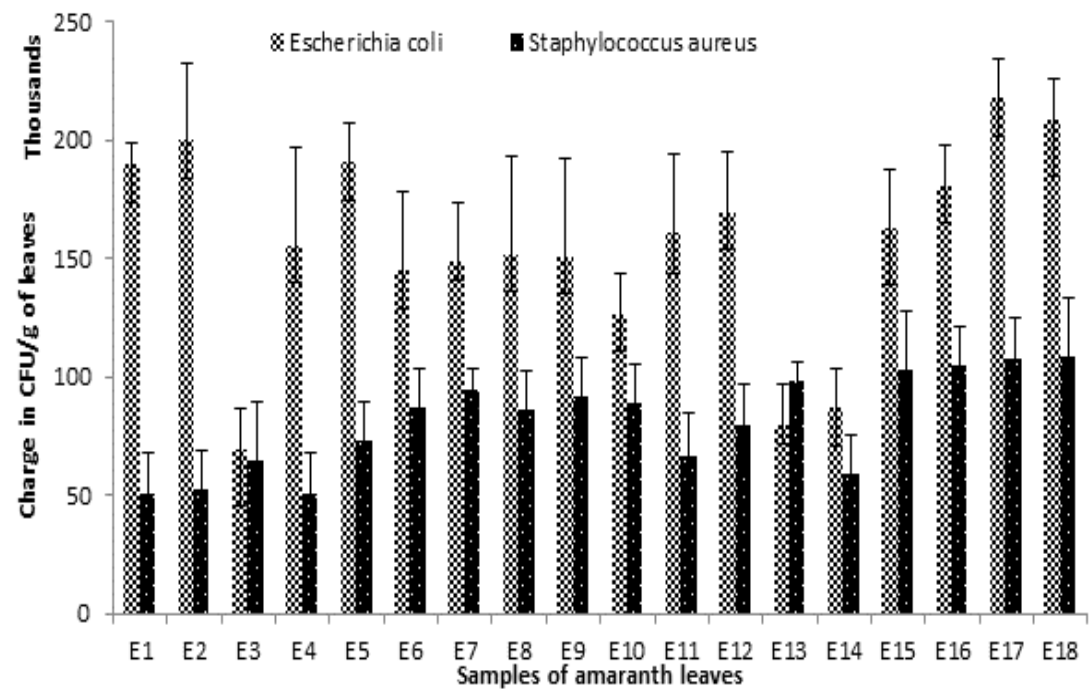

Fig. 5. Numbers in CFU/g of pathogenic bacterial species in amaranth according to the samples 


\subsection{Discussion}

\subsubsection{Characteristics of urban producers of traditional leafy vegetables and diagnosis of production process}

The survey of the different markets of the city of Daloa has identified the most common leafy vegetables consumed by the people of the city. These are amaranth, vegetable cornet, potato leaves, guinea sorrel, basella, black nightshade and african spinach. Indeed, these leafy vegetables are eaten for their great wealth of nutrients, proteins and vitamins. In addition, some have medicinal properties and are consumed to treat various conditions. This information corroborates with the data revealed by reference [7] in their study on the reasons for the cultivation and consumption of leafy vegetables in the areas of Abidjan and Yamoussoukro. The study found that men are not involved in marketing leafy vegetables in Daloa markets. This activity, like most food sales activities, is still confined to women. Women aged between 18 and 30 years $(55.55 \%)$ are the main actors in the marketing of traditional leafy vegetables. This activity would represent a main source of income for most of them. This assertions were supported by references [23] and [24], who indicated that this often-informal activity is proving to be a contribution to urban food security and job creation for vulnerable groups. Leafy vegetables are sold in markets without any hygiene precautions. This situation has also been reported by reference [25]. These authors assert that bags and other materials used for storage represented other factors of microbial contamination at the point of sale. Most of the vendors are either illiterate and have no notion of good hygiene practices. This assertions were supported by references [9] and [26], who have shown that ignorance of hygiene conditions is related to illiteracy or the low level of education of salesgirls. The production of traditional leafy vegetables for the consumption of the population of the city of Daloa is dominated by the female gender, $(63.63 \%)$ against $(36.36 \%)$ for men. The actors in this sector are adults $(90.90 \%$ are aged between 30 and over. These gardeners are mostly uneducated $(72.72 \%)$. These data differ from other data provided by other similar studies. Indeed according to reference [27], in a study conducted in the Abiergue watershed (Yaoundé, Cameroon), the latter showed that market gardening was practiced mainly by men $(77 \%)$ whose age group ranged between 24 and 68 years old. According to work by reference [2], urban and peri-urban production of market gardeners in Abidjan (Côte d'Ivoire) was also dominated by men $(83 \%)$. If the age of producers aged between 30 and over $(90.09 \%)$ could be explained by the arduous nature of gardening work, the sudden and dominant appearance of women could have a purely local explanation. In fact, in agricultural areas dominated by cash crops; men's main activities, food crops, such as market gardening, are left to women. The high rate of illiterate producers $(72.72 \%)$ results from the high rate of illiteracy in the populations of the study area (Haut-Sassandra (61.9\%) according to the reference [28]. The results of reference [7] study of market gardening in Bouaké (Côte d'Ivoire), which revealed that this activity was practiced by people with no education, was also made by reference [29] in Burkina Faso, who indicated that most illiterate men are more likely to practice market gardening. The main inputs for the production of traditional leafy vegetables at the sites surveyed were dung poultry and chemical fertilizer, beef stock market and chemical fertilizer with the mixture of dung, cow purse and chemical fertilizer. In addition, the survey found that ceanes and Runoff water is the most important blades for watering crops (100\%) for market gardening in Daloa. These same practices have been noted in other studies. In a study of the diversity and dynamics of Salmonella isolated from lettuce in Niger, soil amendments were mainly cow bursaries and chemical fertilizer [30]. The use of ceanes or gutters was reported by references [29] and [31]. They say in their research that traditional wells are the most used water sources. In studies on the perception of contamination risks in urban and peri-urban crops, in Accra (Ghana) and in Belgium, the majority of producers used surface water or wastewater for watering vegetables according by references [32] and [33]. The technical production routes of amaranth leaf made by urban producers on the sites investigated are empirical, unconventional or unknown. Some crucial provisions on the boards for a good production (one meter wide with passages of $0.5 \mathrm{~m}$ wide between boards, length 5 or $10 \mathrm{~m}$ maximum) were royally ignored by these producers. In addition, no initial disinfection of the plants was carried out to avoid furs, due among other things to fungi, insects and nematodes. Again, soil amendments (made from poultry and cow purse) were not processed and were used without precautions. All these facts are due to the low level of education of producers. Empirical or rudimentary artisanal production techniques in the production of leafy 
vegetables in this study have been reported in several studies of urban and peri-urban crops $[1,34,35,36]$. The informal nature, the high level of illiteracy and the lack of training programs on good practices in urban farming could justify the behavior of producers who are not aware of the risks of contamination due to market gardening practices. These farming practices would make vegetable production subject to contamination, including microbial contamination.

\subsubsection{Amaranth samples contained diverse microbial contaminants}

Microbiological analyzes revealed microbial contamination of traditional leafy vegetable produced at this study site. All productions were heavily contaminated with mesophilic aerobic germs (GAMs), enterobacteria, yeasts, molds, fecal coliforms and fecal streptococci. Worse, these vegetables were contaminated with Staphylococcus aureus, Escherichia coli and Salmonella $s p$, potential pathogens with varying loads. Regardless of the study site, the CFU/g load of contaminants was well above the thresholds. Levels of microbial contamination of Amaranth leaf sample at market gardening sites varied differently. The mesophilic aerobic germs loads of Amaranth was $1.8 \times 10^{7}$ to $3.45 \times 10^{7}$ $\mathrm{CFU} / \mathrm{g}$ For the fungal flora, the charges ranged from $10^{-6}$ to $2.15 \times 10^{-6} \mathrm{CFU} / \mathrm{g}$ for Amaranth. As for Enterobacteriaceae, the charges ranged

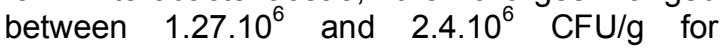
Amaranth. For fecal coliforms and fecal streptococci, the loads for the former ranged from 8.8. $10^{4}$ to $2.36 .10^{5} \mathrm{CFU} / \mathrm{g}$ against 1.23 . $10^{5}$ and $2.54 .10^{5} \mathrm{CFU} / \mathrm{g}$ for the second for Amaranth. These heavy loads could be explained by the lack of hygiene in the production environment on the sites. In addition, the site located in the city center, which is the main receptacle of sewage, sewage and garbage in the city. Charges lower than those obtained during our study were observed by reference [37] in Lagos Nigeria. Indeed, these authors showed that the highest load of mesophilic aerobic germs in the samples of other leaf vegetable was 5.9. $10^{6} \mathrm{CFU} / \mathrm{g}$. This difference could be due to the environment and vegetable cultivation techniques that differ from one country to another. On vegetable production sites, the contamination of leaf vegetables by enterobacteria could be induced by the combination of two factors at least: continuous watering with water of ceanes, the use of poultry manure and the cow purse for soil enrichment. This agrees with observation made by reference
[24] during their work on the social network of market gardeners in Abidjan. Similar observations have been reported by references [9] and [38] respectively in Kumassi (Ghana) and Dakar (Senegal) indicating the involvement of wastewater in the contamination of vegetables produced on vegetable production sites. The same has been done by other authors including $[39,34,2]$ respectively respectively in Lomé (Togo), Kumasi (Ghana) and Abidjan (Côte d'Ivoire). These authors noted that the use of poultry manure and poorly composted manure as fertilizer to fertilize the soil promotes permanent fecal contamination of vegetables. Enterobacteria are normal hosts of the digestive tract of humans and animals, able to proliferate in abundance in the environment and thus participate in major cycles of degradation of organic matter [40]. These are indicators of fecal contamination that provide a more complete picture of potentially pathogenic germs [41]. In addition, the high fecal coliform loads in leafy vegetables at both sites could be explained using beef purse and poultry manure associated with the presence of feces of human origin. Similar observations have been made by reference [37] in their study on E. coli lettuce contamination. In addition, the presence of animals such as reptiles, birds, domestic animals can contribute to fecal contamination of production sites. The excreta of these animals are carried by runoff during the rainy season to the irrigation water sources of the vegetables $[9,39]$ which could explain the presence of these germs in the vegetables. The high rate of fecal streptococci on both production sites is also justified by the presence of animals such as the dog on the sites, the use of the stock market, the droppings as fertilizer and the presence of materials. Feces of human origin. Site yielded a CF/SF Ratio of $0.99(0.7<R<1)$, which indicates predominantly animal mixed-source contamination. Our results corroborate those of several authors, notably reference [9] who reported that wild bird and domestic animal excrement, human excrement, and household waste that end up in unprotected shallow wells on vegetable farms are the source of information fecal contamination of vegetables. Staphylococcus aureus contamination could be explained by a lack of hygiene of market gardeners regardless of the site. Indeed, Staphylococcus aureus is an indicator of manuportage and mucous membranes. According by reference [42], manuported contamination results from human, skin and superficial wounds and animals. Our results confirm those of the work by references [43] and 
[44] who indicated that excessive handling of vegetables contributes to increased risk of $S$. aureus contamination. The presence of this bacterium in vegetable samples reflects poor hygiene practices in the production chain and poses a risk to the health of consumers. $S$. aureus is a pathogenic bacterium responsible for food poisoning [45]. Escherichia coli were detected in all analyzed samples. Escherichia coli are pathogens (diarrhea) that are usually found in environments where health conditions are precarious $[46,47]$. Therefore, the consumption of these vegetables without any precautions could be associated with diarrheal diseases [48]. In addition, the presence of pathogens indicates that good hygienic practices are not observed during production [49]. In this study, all leafy vegetables were contaminated with Salmonella sp. This species was found with different proportions in the analyzed samples. The use of poultry droppings, the presence of domestic animals such as pigs and cold-blooded, wild animals like frogs and lizards and poor sanitary conditions on vegetable production site could explain the presence of this species. According to some authors, the references $[50,51]$, enteric pathogens would be the main contaminant of vegetables because of poor hygiene practices.

\section{CONCLUSION}

The cultivation of traditional leafy vegetables from urban production is a reality in the city of Daloa. This work first allowed inventorying the seven main species of traditional leafy vegetables consumed by the people of the city of Daloa. Monitoring the urban production of these traditional leafy vegetables in Daloa revealed that the majority of actors in this sector were adults (> 30 years old), female dominated $(63 \%)$ and poorly educated $(72 \%$ illiterate). The technical production routes observed at amaranth production site remained very empirical. The wastewater used for watering crops, the use of chicken manure, the beef purse and other chemicals without any precautions and without any treatment as fertilizer would make the production of traditional leafy vegetables including Amaranth subject to any contamination, especially microbial contamination. Microbiological analyzes showed that amaranth produced was heavily contaminated by different flora, especially indicator flora of general pollution and fecal flora. Worse, it has been noted the presence of pathogenic bacterial species such as
Staphylococcus aureus, Escherichia coli and Salmonella sp. However, the origin of the fecal contamination of the site is mixed predominantly animal. The strong presence of these germs would translate into a marked deficit of good production and hygiene practices in the study sites, which would represent a danger for consumers. Amaranth leaf produced at the study site investigated is not suitable for human consumption.

Thus, the competent authorities must raise awareness and raise awareness of the health risks to consumers. Establishing regulations for urban agriculture could limit the risk of contamination.

\section{ACKNOWLEDGEMENTS}

There has been no source of funding. The authors thank the University of Jean Lorougnon Guédé of Daloa.

\section{COMPETING INTERESTS}

Authors have declared that no competing interests exist.

\section{REFERENCES}

1. Kouassi KC, Kouassi KA, Yao KM, Kouassi AG, Koffi NR. Assessment of the risk of microbial contamination of an urban crop in the city of Daloa (Côte d'Ivoire): Case of Lettuce (Lactuca sativa L.). J. Food Res. 2019;8(3):122-132.

2. Koffi NR, Assi CBJ, Assemand EF, Wognin AS. Origin of faecal contamination of irrigation water of lettuce (Lactuca sativa) grown in the peri-urban area of Abidjan. J. Appl. Biosci. 2012;52:3669-3675.

3. Aubry JP. Urban agriculture is already part of the urban metabolism. The Demeter 2013. Nature and agriculture for the city. 2013;140:135-155.

4. Ogoye-Ndegwa C, Aagaard-Hansen J. Traditional gathering of wild vegetables among the Luo of western Kenya a nutritional anthropology project. J. Ecolo. Food Nutr. 2003;69-89.

5. Bayendi LSM, Ndoutoume AN, Frédéric F. Le maraîchage périurbain à Libreville et Owendo (Gabon): Pratiques culturales et durabilité entomologie fonctionnelle et évolutive, Cah. Agric. 2017;26:45002.

6. Idogun ES, Famodu AA, Olasunkanmi LA, Osilesi O, Adebawo OO. Effects of hypertensive patients and electrolytes on 
blood pressure patients seen in Nigeria. Afr. J. Food Agric. Nutr. Dev. 2008;8(3): 349-357.

7. Fondio L, Kouame C, Djidji AH, Traore D. Characterization of culture systems incorporating okra in urban and peri-urban market gardening of Bouaké in Central Côte d'Ivoire. Int. J. Biol. Chem. Sci. 2011; 5(3):1178-1189.

8. Atchibri OLA, Soro LC, Kouamé C, Agbo EA, Kouadio KKA. Nutritional values of leafy vegetables consumed in Côte d'Ivoire. Int. J. Biol. Chem. Sci. 2012;6(1): 128-135.

9. Amoah $\mathrm{P}$, Drechsel $\mathrm{P}$, Abaidoo $\mathrm{R}$, Henseler $M$. Irrigated urban vegetable production in Ghana: Microbiological contamination in farms and markets and associated consumer risk groups. J. Water Health. 2007;5(2):455-467.

10. Petterson SR, Ashbolt NJ, Sharma A. Microbial risks from wastewater irrigation of salad crops: A screening-level risk assessment. J Food Sci. 2010;75(5):283290.

11. Koffi-Nevry R, Manizan NP, Wognin AS, Koussemon M, Koffi OS, Kablan T, et al. Characterization of the spatio temporal distribution of bacteria at the water interface sediment of a Tropical Lagoon: Case of Banco Bay, Abidjan, Ivory Coast. Eur. J. Sci. Res. 2008;21:164174.

12. Wendel AM, Johnson DH, Sharapov U, Grant J, Archer JR, Monson T. Multistate outbreak of Escherichia coli O157: H7 infection associated with sputum packaged consumption, August-September 2006: The Wisconsin investigation. Clin. Infect. Dis. 2009;48:1079-1086.

13. World Health Organization (WHO). Weekly Epid Rev. 2004;18(6):253-264.

14. ISO 4833-1 (1). Horizontal method for enumeration of microorganisms - Colony count at $30^{\circ} \mathrm{C}$ by deep seeding technique. 2013;1-28.

15. ISO 21528-2 (1). Horizontal methods for the detection and enumeration of Enterobacteriaceae - Part 2: Colony-count method. 2004;1-28.

16. NF/ISO 16212. Cosmetics - Microbiology Enumeration of yeasts and molds. 2011;14.

17. ISO 4832. Horizontal method for the enumeration of coliforms - Colony count method. 2006;1-28.
18. NF EN ISO 7899-2. Investigation and enumeration of intestinal enterococci - Part 2: membrane filtration method. 1998;1-28.

19. ISO 6888-1 (1). Horizontal method for enumeration of coagulase-positive staphylococci (Staphylococcus aureus and other species) - Part 1: Technique using Baird-Parker agar medium. 2009;1-28.

20. AFNOR BRD-07/20-03/11. Rapid E. coli 2 + Water Testing. 2019; 1- 28.

21. ISO 6579/Amd (1). Horizontal method for the detection of Salmonella spp. 2007;112.

22. Ndiaye NA, Dieng $M$, Kane A, Cisse $M$, Montet D, Toure NC. Diagnosis and microbiological characterization of artisanal processes for the manufacture of Hibiscus sabdariffa $L$ beverages and concentrates in Senegal. Africa Science. 2015;11(3): 197-210.

23. Pereira EL, Rodrigues A, Ramalhosa E. Influence of working conditions and practices on fresh-cut lettuce salads quality, Food Control. 2013;33:406-12.

24. Matthys B, Adiko A, Tschannen AB, Cissé G, Tanner M, Utzinger J. Market gardeners in Abidjan, Côte d'Ivoire: Health concerns and parasitic diseases. Magazine Urban Agriculture. 2007;2:5-12.

25. Aubry $\mathrm{C}$, Dabat $\mathrm{MH}$, Mawois $\mathrm{M}$. Food Function of Urban Agriculture in North and South: Permanence and Renewal of Research Questions- Innovation and Sustainable Development; In Agriculture and Food. 2010;1-12.

26. Gueye NFD, Sy M. The valorisation of wastewater for urban agriculture: The example of Dakar, Nouakchott and Ouagadougou. Urban Agriculture Magazine. 2001;1(3):30-32.

27. Kenmongue GR, Rosillon F, Mpakam HG, Nono A. health issues, socio - economic et environment related to wastewater reuse in urban gardening: If the watershed of Abiergué (Yaounde-Cameroon). Water, Waste and Sustainable Development Symposium. 2010;1-25.

28. INS. Institut National de Statistique, recensement général de la population et de l'habitation (RGPH, 2014), répertoire des localités : Région du Haut-Sassandra. $2015 ; 42$.

29. Kolié JP. Identification of group e s homogeneous market gardeners and assessment of their economic performance 
in Burkina Faso. "Master of Science" Series No. 101 of the Mediterranean Agronomic Institute of Montpellier. 2009;1116.

30. Alio SA, Inoussa MM, Bakasso Y, Samna SO. Diversity and dynamics of Salmonella isolated from lettuce (Lactuca sativa L.) in vegetable crops in Niger (West Africa). J. Appl. Biosci. 2017;119:11917-28.

31. Adiko A, Matthys B, Cisse G, Bonfoh B, Tanner M, Utzinger J. Relation between the human capital of urban market gardeners and their behavior to prevent health risks on cultivation sites in Abidjan (Côte d'Ivoire), VertigO. 2010; 10(2):1-9.

32. Keraita B, Drechsel $P$, Konradsen $F$. Perceptions of farmers on health and risk reduction in wastewater irrigated urban vegetable farming in Ghana. J. Risk Res. 2008;11 (8):1047-61.

33. Holvoet K, Sampers I, Seynnaeve M, Uyttendaele M. Relationships among hygiene indicators and pathogens in water irrigation, soil and lettuce and the impact of climatic conditions on contamination in the lettuce primary production. Int. J. Food Microbiol. 2014;171:21-31.

34. Amponsah-Doku F, Obiri-Danso K, Abaidoo RC, Andoh LA. Bacterial contamination of lettuce and associated risk factors at production sites, markets and street food restaurants in urban and peri-urban Kumasi, Ghana. Sci. Res. Essays. 2010;5(2):217-23.

35. Soendjojo E. Is local produce safer? Microbiological quality of fresh lettuce and spinach from grocery stores and farmers' markets. JPUR Journal of Purdue Undergraduate Research. 2012; 2:54-63.

36. Woldetsadik D, Drechsel P, Keraita B, Itanna F. Microbiological quality of lettuce (Lactuca sativa) irrigated with wastewater in Addis Ababa, Ethiopia and the effect of green salads washing methods. Int. J. food contam. 2017;4(3).

37. Uzeh RE, Alade FA, Bankole M. The microbial quality of prepacked mixed vegetable salad in some retail outlets in Lagos, Nigeria. African. J. Food Sci. 2009; 3(59):270-272.

38. Gaye M, Niang S. Handbook of Good Practices for the Safe Use of Wastewater in Urban Agriculture. Relay for Popular Urban Development; Dakar-Senegal. 2010;1-131.
39. Adjrah A, Karou DS, Jeri B, Anani K, Soncy K, Ameyapoh $\mathrm{Y}$ et al. Hygienic quality of commonly consumed vegetables, and perception of disinfecting agents in Lome. International. Food Research. Newspaper. 2011;18(4):1499-1503.

40. Geser N, Stephan R, Korczak M, Beutin L, Hachler $H$. Molecular identification of extended-spectrum-beta-lactamase genes from Enterobacteriaceae Isolated from healthy human carriers in Switzeerland. Antimicrob. Agents Chemo. 2012;56:16091612.

41. Anonymous, Enumeration of Enterobacteriaceae in food samples and environmental using Numbering plates enterobacteria petrifies 3mc. Health Products and Food Branch Ottawa, Canada MFLP-09. 2007 ;2:1-5.

42. Burt M, Volel C, Finkel M. Safety of sell or prepared foods; Evaluatuion of processing mobile food vendors in Manhattan. Public Health Report. 2003;118:470-476.

43. Abdalla MA, Suliman SE, Bakhiet AO. Food safety knowledge and praction of street food vendors in Atbara City (Naher Elneel State Sudan). Afric. J. Biotech. 2009;8(24):6967-6971.

44. Elfaki AE, Elhakim SAA. Quality evaluation of two sudanes street food of animal origin. Adv. J. Food Sci. Techno. 2011;3(3):219223.

45. Ameko E, Achio S, Alhassan S, Kassim A. Microbial safety of raw mixed vegetables salad served in Accra, Ghana. African. J. Biotechn. 2012;11(50):11078-11085.

46. Nwankwo IU, Eze VC, Onwuakor CE, Friday JU. Evaluation of the degree of contamination of salad vegetables sold in Umuahia main market. Am. J. Microbiol. Res. 2015;3(1):41-44.

47. Mesa RJ, White V, Blanch AR. Extended-spectrum beta-lactamaseproducing Enterobacteriaceae in different environments (humans, food, animal farms and sewage). J. Antimicrob.Chem. 2006; 58(1):211-215.

48. Hanoshiro A, Morita M, Matte M, Torres E. Microbiological quality of selected foods from Sao Pau-lo city, Brazil, Food control. 2004;16:439-440.

49. Chumber S, Kaushik S, Savy S. Bateriological analysis of street foods in Pune. Ind. J. Pub. Health. 2007;51:114116.

50. Mañas $\mathrm{P}$, Castro E, Las-Heras J. Irrigation with treated wastwater: 
Effects on soil, lettuce (Lactuca sativa L.) and microorganisms. Journal of Environmental Science and Health. Part A. Toxic / hazardous substances \& environmental engineering. 2009;44(12): 1261-1273.
51. Tham J, Odenholt I, Walder M, Brolund A, Ahl J, Melander E. Extended spectrum beta-lactamase-producing Escherichia coli in patients with travelers'diarrhoea. Scand Journal Infectious Diseases. 2010;42(4): 275-280.

(c) 2019 Kouassi et al.; This is an Open Access article distributed under the terms of the Creative Commons Attribution License (http://creativecommons.org/licenses/by/4.0), which permits unrestricted use, distribution, and reproduction in any medium, provided the original work is properly cited.

Peer-review history:

The peer review history for this paper can be accessed here: https://sdiarticle4.com/review-history/51797 